\title{
Learning Styles and Personality Types of Freshman Level Pre- Athletic Training Major Students
}

Marketa Schublova

Slippery Rock University of Pennsylvania, marketa.schublova@sru.edu

Follow this and additional works at: https://nsuworks.nova.edu/ijahsp

Part of the Health and Physical Education Commons, and the Medicine and Health Sciences

Commons

This Manuscript has supplementary content. View the full record on NSUWorks here:

https://nsuworks.nova.edu/ijahsp/vol15/iss4/6

\section{Recommended Citation}

Schublova M. Learning Styles and Personality Types of Freshman Level Pre-Athletic Training Major Students. The Internet Journal of Allied Health Sciences and Practice. 2017 Jan 01;15(4), Article 6.

This Manuscript is brought to you for free and open access by the College of Health Care Sciences at NSUWorks. It has been accepted for inclusion in Internet Journal of Allied Health Sciences and Practice by an authorized editor of NSUWorks. For more information, please contact nsuworks@nova.edu. 


\title{
Learning Styles and Personality Types of Freshman Level Pre-Athletic Training Major Students
}

\begin{abstract}
Purpose: The purpose of this study was to determine the preferred learning style and personality types of freshman-level pre-athletic training students. The secondary purpose was to identify any possible differences in learning styles and personality types of students admitted into the athletic training program versus those that were denied admission or changed their major. Methods: Data collection took place during a college introductory course over a period of seven years. Four hundred seventy-two freshmen (188 men, 284 women; average age $18.66 \pm 0.87$ years) considering athletic training as their major at a CAATE-accredited athletic training program participated in this study. A 48-item Kolb's Learning Style Inventory questionnaire and 126-question Myers-Briggs Type Indicator form G were used to determine students' preferred learning style and personality types. Results: The most common personality types among pre-athletic training students were Extraversion, Sensing, Thinking, Perception (ESTP) (14.2\%) and Introversion, Sensing, Thinking, Judging (ISTJ) (13.3\%), and $35.8 \%$ of pre-athletic training students preferred accommodator learning style. However, converger learning style was the most common (30\%) among students admitted into the athletic training program. The most common personality type for students admitted into the athletic training program was Extraversion, Sensing, Thinking, Judging (ESTJ). This was true for both groups of admitted and not admitted students. Personality types of students specific to their preferred learning styles were also examined. Accommodators placed in Extraverted, Sensing, Thinking, Judging (ESTJ) category (21\%), divergers in Extraverted, Sensing, Feeling, Judging (ESFJ) category (14.9\%), convergers in Extraverted, Sensing, Thinking, Perception (ESTP) (22\%), and assimilators in Extraverted, Sensing, Thinking, Judging (ESTJ) (14.7\%) category. Conclusions: Based on the findings of this study, freshman pre-athletic training students demonstrated great diversity in their learning styles and personality types. These students prefer hands-on learning, rely on each other to solve a problem, enjoy solving problems, and excel in finding practical use while learning. They benefit from multimodal teaching methods. Educators should consider integrating concrete and abstract material into the curriculum. Athletic training students need to have the ability to participate in all different learning style preferences because athletic training is a science-based profession where abstract conceptualization is important along with effective interpersonal relationships with their patients and ability to act effectively in critical situations.
\end{abstract}

\section{Author Bio(s)}

Dr. Markéta Schüblová is an assistant professor in the Athletic Training program at Slippery Rock University of Pennsylvania since 2007. She serves as the Clinical Education Coordinator. Dr. Schüblová completed her doctoral degree in Higher Education Curriculum and Instruction with a concentration in Athletic Training at Ohio University. Dr. Schüblová's clinical research focuses on thermoregulation and her didactical research include critical thinking, clinical reasoning, learning styles and personality types of athletic training students. 


\title{
TIAHSP \\ The Internet Joưnal of Allied Health Sciences and Practice
}

Dedicated to allied health professional practice and education

Vol. 15 No. 4 ISSN 1540-580X

\section{Learning Styles and Personality Types of Freshman-Level Pre-Athletic Training Major Students}

\author{
Marketa Schublova, Ph.D. \\ Slippery Rock University of Pennsylvania \\ United States
}

\begin{abstract}
Purpose: The purpose of this study was to determine the preferred learning style and personality types of freshman-level preathletic training students. The secondary purpose was to identify any possible differences in learning styles and personality types of students admitted into the athletic training program versus those that were denied admission or changed their major. Methods: Data collection took place during a college introductory course over a period of seven years. Four hundred seventytwo freshmen (188 men, 284 women; average age $18.66 \pm 0.87$ years) considering athletic training as their major at a CAATEaccredited athletic training program participated in this study. A 48-item Kolb's Learning Style Inventory questionnaire and 126question Myers-Briggs Type Indicator form $G$ were used to determine students' preferred learning style and personality types. Results: The most common personality types among pre-athletic training students were Extraversion, Sensing, Thinking, Perception (ESTP-14.2\%) and Introversion, Sensing, Thinking, Judging (ISTJ-3.3\%); 35.8\% of pre-athletic training students preferred accommodator learning style. However, converger learning style was the most common (30\%) among students admitted into the athletic training program. The most common personality type for students admitted into the athletic training program was Extraversion, Sensing, Thinking, Judging (ESTJ). This was true for both groups of admitted and not admitted students. Personality types of students specific to their preferred learning styles were also examined. Accommodators placed in Extraverted, Sensing, Thinking, Judging (ESTJ) category (21\%), divergers in Extraverted, Sensing, Feeling, Judging (ESFJ) category (14.9\%), convergers in Extraverted, Sensing, Thinking, Perception (ESTP-22\%), and assimilators in Extraverted, Sensing, Thinking, Judging (ESTJ-14.7\%) category. Conclusions: Based on the findings of this study, freshman pre-athletic training students demonstrated great diversity in their learning styles and personality types. These students prefer hands-on learning, rely on each other to solve a problem, enjoy solving problems, and excel in finding practical use while learning. They benefit from multimodal teaching methods. Educators should consider integrating concrete and abstract material into the curriculum. Athletic training students need to have the ability to participate in all different learning style preferences because athletic training is a science-based profession where abstract conceptualization is important along with effective interpersonal relationships with their patients and ability to act effectively in critical situations.
\end{abstract}

\section{INTRODUCTION}

Athletic training education is a unique and challenging major because of the time-consuming and rigorous nature of the didactic and clinical components of the curriculum.1,2 Athletic training students are required to master the content knowledge necessary to be competent in this field and must possess the ability to apply their clinical skills in a variety of settings and under a variety of circumstances by utilizing their critical thinking and problem-solving skills. Furthermore, athletic training students must be able to effectively communicate, interact, and collaborate with patients, administrators, and healthcare providers. ${ }^{3}$

A major component of healthcare education is a hands-on experience where students learn through observation, contemplation, and experimentation. It would be beneficial for athletic training faculty to identify the learning styles of their students to organize and disseminate content accordingly to increase students' motivation to learn and retention of knowledge. Based on Kolb and Kolb's research, giving students the opportunity to recognize their learning styles allows them to be proactive in improving their learning challenges. ${ }^{4}$ Because of the challenging and varied nature of the knowledge and skills required of this particular major, it is important to investigate the learning styles and personality characteristics that may be best suited for students entering this 
profession. Dunn et al and Partridge concluded in their studies that identifying and teaching to students' learning styles has been beneficial in their education. 5,6 By classifying and understanding students' learning styles, it enables educators to modify the teaching strategies to facilitate the most efficient learning and mentor their students to be successful in the athletic training profession.

Kolb's Learning Style Inventory (LSI) has been the most frequently used instrument to evaluate individual's preferred learning style. ${ }^{1,2,7}$ Kayes reported internal reliability correlation coefficient ranges from .77 to .84 on four-dimensional constructs of LSI. ${ }^{8}$ Kolb reported similar findings of correlation coeficient ranging from .77 to $.84 .{ }^{9}$ Kolb's LSI questionnaire is a 48 -item self-reported questionnaire asking participants to rank four statements for each question describing individual's preferred way to learn. These four words in each question represent the four steps in Kolb's experiential learning cycle. Kolb's LSI questionnaire is designed to assess the strengths and a weakness of a student's learning style. It classifies learners into two dimensions: active-reflective and concrete-abstract. It is based on Kolb's cycle and described as concrete experience (CE), reflective observation (RO), abstract conceptualization (AC) and active experimentation (AE). Kolb's LSI measures how much learners emphasize abstractness over concreteness and action over reflection. Not a single individual's learning style is only one of the modes; rather, an individual's learning style is a combination of these learning modes. ${ }^{10}$ Table 1 provides an overview of Kolb's learning style preferences. ${ }^{10,11}$

Table 1. Kolb's Learning Styles Overview

\begin{tabular}{|c|c|}
\hline \multicolumn{2}{|r|}{ Kolb's Learning Styles } \\
\hline Accommodator & $\begin{array}{l}\text { - } \text { Prefers hands-on learning } \\
\text { - } \text { Acts on gut feelings rather than logic } \\
\text { - Relies on people for information to solve a problem } \\
\text { - } \quad \text { Concrete experience/active experimentation CE/AE } \\
\text { - Preferred careers: art, history, political science, foreign language }\end{array}$ \\
\hline Diverger & $\begin{array}{l}\text { - } \text { Tends to view situations from different points of view } \\
\text { - } \quad \text { Prefers observation over action } \\
\text { - } \quad \text { Enjoys brainstorming } \\
\text { - } \quad \text { Concrete experience/reflective observation CE/RO } \\
\text { - } \quad \text { Preferred careers: education, communication or management }\end{array}$ \\
\hline Assimilator & $\begin{array}{l}\text { - } \text { Proficient in translating information into logical form } \\
\text { - } \quad \text { Likes abstract ideas and concepts } \\
\text { - } \text { Enjoys creating theories and models } \\
\text { - } \quad \text { Abstract conceptualization/reflective observation AC/RO } \\
\text { - } \quad \text { Preferred careers: physics, mathematics, education, law, and biology }\end{array}$ \\
\hline Converger & $\begin{array}{l}\text { - } \text { Excels in finding practical use } \\
\text { - } \quad \text { Enjoys solving problems and making decision } \\
\text { - } \quad \text { Prefers technical tasks over social and interpersonal issues } \\
\text { - } \quad \text { Abstract conceptualization/active experimentation AC/AE } \\
\text { - } \quad \text { Preferred careers: medicine, economics, and computer science }\end{array}$ \\
\hline
\end{tabular}

Learning styles can change over time, and factors such as personality type, learning environment, and educational specialization can influence them..$^{12}$ According to Gurpinar et al, students' learning styles change over time depending on their field of study. ${ }^{11}$ Students in a medical field of study are most commonly identified as assimilators or convergers. ${ }^{11,13,14}$ Gurpinar et al investigated changes in medical students' learning styles within the first two years of their training. They concluded that the largest change from the beginning of students' training to the end of their second year was in the group of divergers that shifted into the assimilating (58.6\%) and converging $(27.6 \%)$ learning styles. ${ }^{11}$ Changes in assimilators and convergers groups to other learning styles were minimal (5\%). These changes into assimilating and converging learning styles support the assumption that students in healthcare fields of study prefer this type of learning. Medical students preferred taking classes with faculty using assimilating and converging teaching methods and did not change their preferred learning style. ${ }^{11}$ According to Kolb, divergers are weak in decision making, knowledge assessment, and in deciding what to learn. Accommodators have a difficult time in task execution

(C) The Internet Journal of Allied Health Sciences and Practice, 2017 
and managing their time..$^{10}$ This supports the assumption that divergers and accommodators prefer careers other than those in a medical field and if they choose a medical major, they tend to change their learning style over time to assimilating or converging. ${ }^{10}$ Students in healthcare fields are mainly assimilators and convergers who typically prefer to learn through observation, contemplation, and experimentation. ${ }^{11}$

Isabel Briggs Myers and Katharine Briggs created the Myers-Briggs Type Indicator (MBTI). It is an instrument using 126 forced questions and placing participants into sixteen personality types based on measurements in four areas: 1) introversion/extraversion (I/E), 2) thinking/feeling (T/F), 3) sensing/intuition (S/N), and(4) judging/perceiving (J/P). Introverts prefer the interior world of ideas and extraverts prefer the external world of people and objects. Thinkers tend to make their decision on logical analysis and feelers base their decisions primarily on person-oriented subjective evaluations. Individuals preferring sensing focus on information gained through the senses and individuals with a dominant intuitive focus on future, imagination, and possibilities. Judgers tend to focus on planned and organized approaches while individuals preferring perceiving function are spontaneous and flexible. ${ }^{15}$ Healthcare professionals are primarily thinkers and sensors with Extraverted, Sensing, Thinking, Judging (ESTJ) and Introverted, Sensing, Thinking, Judging (ISTJ) personality types. ${ }^{16}$

The Myers-Briggs Type Indicator is an instrument that uses Jung's theory of psychological types. ${ }^{17}$ Jung characterized the basic kinds of mental operations as thinking, feeling, sensing, and intuition. It is a self-reported questionnaire designed to explain the differences in how people perceive the world and make decisions. Carlyn ${ }^{18}$ reported that MBTI is an adequately reliable selfreport inventory. ${ }^{18}$ The Myers-Briggs Type Indicator score is about $70 \%$ accurate when measured against the actual behavior. ${ }^{16}$ The questionnaire form $\mathrm{G}$ consists of 126 forced-choice questions, and the scores indicate a person's preference in each of four dichotomous areas. These four dichotomies are extraversion versus introversion, sensing versus intuition, thinking versus feeling, and judging versus perceiving. Every individual has access to all of these dichotomies, but one of them will be more readily available and will become dominant. ${ }^{16}$ Table 2 provides some characteristics of the various preferences in Jung's four personality areas..$^{19}$

There are 16 personality types used to place people in based on their answers. ${ }^{15}$ Administering the MBTI in education can assist educators and help students understand different personality types and how they might affect learning. These scores can possibly explain a preference to specific learning methods. ${ }^{17}$ It can assist students and educators in understanding their own preferred learning and teaching styles. Thus, the MBTI can assist in the development of different teaching methods and the understanding of preferred learning styles.

Table 2. Myers-Briggs Type Indicator Overview Myers-Briggs Type Indicator

\begin{tabular}{|c|c|c|}
\hline $\begin{array}{l}\text { Where people focus their } \\
\text { energy }\end{array}$ & $\begin{array}{l}\text { Extroversion/E } \\
\text { - Focuses on the outer world of people and } \\
\text { activity }\end{array}$ & $\begin{array}{l}\text { Introversion/l } \\
\text { - Focuses on the inner world of } \\
\text { ideas and impressions }\end{array}$ \\
\hline $\begin{array}{l}\text { The way people take in } \\
\text { information }\end{array}$ & $\begin{array}{l}\text { Sensing/S } \\
\text { - Takes information through the five } \\
\text { senses, focusing on here and now }\end{array}$ & $\begin{array}{l}\text { Intuition/N } \\
\text { - Takes information from patterns } \\
\text { and the big picture, focuses on } \\
\text { future }\end{array}$ \\
\hline $\begin{array}{l}\text { The way people make } \\
\text { decisions }\end{array}$ & $\begin{array}{l}\text { Thinking/T } \\
\text { - } \quad \text { Makes decision based on logic and } \\
\text { objectives analyzing cause and effect }\end{array}$ & $\begin{array}{l}\text { Feeling/F } \\
\text { - } \quad \text { Makes decision based on values } \\
\text { and subjective evaluation of } \\
\text { person-centered concerns }\end{array}$ \\
\hline $\begin{array}{l}\text { The way people deal with the } \\
\text { outer world }\end{array}$ & $\begin{array}{l}\text { Judging/J } \\
\text { - Likes a planned and organized approach } \\
\text { to life. Likes to have things settled }\end{array}$ & $\begin{array}{l}\text { Perceiving/P } \\
\text { - Likes a flexible and spontaneous } \\
\text { approach to life. Keeps their } \\
\text { options open }\end{array}$ \\
\hline
\end{tabular}

The purpose of this study was to determine if pre-athletic training freshmen prefer a specific learning style or possess a specific personality type. The secondary goal was to identify any possible differences in learning styles and personality types of students admitted into the athletic training program versus those that were denied admission or who voluntarily changed their major.

(C) The Internet Journal of Allied Health Sciences and Practice, 2017 
Understanding the learning styles and personality types of pre-athletic training students, who may or may not eventually become athletic trainers, would be beneficial to faculty. The Kolb's Learning Style Inventory and the MBTI were used in this study to determine preferred learning styles and personality characteristics of pre-athletic training students.

\section{METHODS}

The institutional review board approved this study. A total of 472 freshmen (188 men, 284 women; average age $18.66 \pm 0.87$ years) pre-athletic training majors enrolled in the Introduction to Athletic Training class at a Commission on Accreditation of Athletic Training Education accredited program during 2008-2009 through 2014-2015 academic years participated in this study. Three hundred twenty-four (69\%) were not admitted into the professional strand of the athletic training program, $137(29 \%)$ gained admittance after their first application, 9 (1.9\%) re-applied and were admitted on their second trial the following year, 2 $(0.4 \%)$ were admitted and changed their major during their first year in the program.

Data collection took place during a college introductory course over a period of seven years. All pre-athletic training students received the LSI and MBTI questionnaires during class and were provided as much time as needed to answer all questions. Each of these questionnaires was administered on a different day to eliminate a potential decrease in students' interest to complete the forms. These questionnaires were implemented in an introductory class because the faculty believed that understanding learning styles and personality types of students was beneficial to students themselves and also to faculty. After the analysis of the questionnaires, the faculty members organized class activities to provide students with feedback regarding their personality types and learning styles. Those activities provided students with different scenarios allowing them to see and reflect on how they would react in each situation compared to their classmates with different personality types. During those activities, students saw a different view of the provided scenarios from their peers with justifications why we do what we do in different situations. The students also discussed their preferred learning styles. They saw that students with different preferred learning styles enjoyed different classes based on their preference and used different learning methods from "say it loud" method to making flash-cards. Hands on students stated they enjoyed anatomy lab and learning by playing with the models while others did not like labs but enjoyed the theory lecture in classrooms. The students learned to work together to help each other on different topics by using each other's preferred learning style.

After these activities, students were asked to participate in this study by allowing the researcher to access and analyze their data. The researcher provided students with an informed consent document and an envelope. Students who wanted to participate signed the consent form and placed it in the envelope. Students who did not want to be a part of this study placed a blank consent form into the envelope. The envelopes were sealed by students and kept in a locked cabinet in the investigator's office for one year. The investigators opened the envelopes and analyzed the data after a year to eliminate any biases during the program admission process.

Frequency distributions were calculated to determine the percentage of participants that preferred each learning style and were placed in different personality type categories. Chi-square $\left(x^{2}\right)$ test was used to compare differences in learning style and personality types between freshmen admitted into the professional strand of athletic training program and students who were denied and/or changed their major during their first year of college. An a of $p \leq .05$ was chosen a priori to indicate significance.

\section{RESULTS}

Freshman level pre-athletic training students proved to be very diverse in their learning styles and personality types. Table 3 provides data summary of personality type distribution among pre-athletic training students. There was no significant difference in any learning preference or personality type using the following preferred personal characteristics: I/E, S/I, T/F, J/P. (See Table 2 for more details regarding preferred characteristics of participants.) The most common personality types among pre-athletic training students were Extraversion, Sensing, Thinking, Perception (ESTP, 14.2\%) and ISTJ (13.3\%), and $35.8 \%$ of pre-athletic training students preferred accommodator learning style. Although not statistically significant, students that gained admission into the professional strand of athletic training program proved to be mainly ESTJ (21.3\%), Extraversion, Sensing, Feeling, Judging (ESFJ, 19.1\%) with converger (30\%) and accommodator $(28.1 \%)$ learning styles. Table 4 provides distribution of learning styles among pre-athletic training students. Personality types of students specific to their preferred learning styles were also examined. Accommodators placed in ESTJ (21\%) category, divergers in ESFJ (14.9\%) category, convergers in ESTP (22\%), and assimilators in Extraverted, Sensing, Thinking, Judging (ESTJ, 14.7\%) category. Students with no strong preferred learning style placed in Extraverted, Intuition, Thinking, Perceiving (ENTP, 30\%) and Introverted, Sensing, Thinking, Perceiving (ISTP, 30\%) categories the most. Table 5 shows preferred skills and personality differences for these most common categories in personality types and learning styles.

() The Internet Journal of Allied Health Sciences and Practice, 2017 
Table 3. Myers-Briggs Type Indicator for Pre-Athletic Training Students

\begin{tabular}{|c|c|c|c|c|c|c|c|c|}
\hline \multicolumn{7}{|c|}{ Myers-Briggs Profiles } \\
\hline Group & ISTJ & ISFJ & INFJ & INTJ & ISTP & ISFP & INFP & INTP \\
\hline Denied & $10.1 \%$ & $6.3 \%$ & $0.3 \%$ & $0.9 \%$ & $6.9 \%$ & $4.4 \%$ & $1.3 \%$ & $1.6 \%$ \\
\hline Admitted 1 time & $9.6 \%$ & $7.3 \%$ & $0.0 \%$ & $0.0 \%$ & $5.2 \%$ & $1.5 \%$ & $1.5 \%$ & $1.5 \%$ \\
\hline Admitted 2 time & $11.1 \%$ & $11.1 \%$ & $0.0 \%$ & $0.0 \%$ & $22.2 \%$ & $0.0 \%$ & $0.0 \%$ & $0.0 \%$ \\
\hline Change of major & $0.0 \%$ & $0.0 \%$ & $0.0 \%$ & $0.0 \%$ & $0.0 \%$ & $0.0 \%$ & $0.0 \%$ & $0.0 \%$ \\
\hline Total & $9.9 \%$ & $6.7 \%$ & $0.2 \%$ & $0.6 \%$ & $6.7 \%$ & $3.4 \%$ & $1.3 \%$ & $1.5 \%$ \\
\hline
\end{tabular}

\begin{tabular}{|c|c|c|c|c|c|c|c|c|}
\hline \hline \multicolumn{9}{|c|}{ Myers-Briggs Profiles } \\
\hline Group & ESTP & ESFP & ENFP & ENTP & ESTJ & ESFJ & ENFJ & ENTJ \\
\hline Denied & $14.2 \%$ & $10.4 \%$ & $7.6 \%$ & $5.4 \%$ & $13.3 \%$ & $10.7 \%$ & $4.1 \%$ & $2.5 \%$ \\
\hline Admitted 1 time & $11.0 \%$ & $6.6 \%$ & $4.4 \%$ & $2.9 \%$ & $21.3 \%$ & $19.1 \%$ & $6.6 \%$ & $1.5 \%$ \\
\hline Admitted 2 time & $0.0 \%$ & $0.0 \%$ & $0.0 \%$ & $0.0 \%$ & $55.6 \%$ & $0.0 \%$ & $0.0 \%$ & $0.0 \%$ \\
\hline Change of major & $0.0 \%$ & $0.0 \%$ & $0.0 \%$ & $50.0 \%$ & $0 \%$ & $50.0 \%$ & $0.0 \%$ & $0.0 \%$ \\
\hline Total & $12.9 \%$ & $9.1 \%$ & $6.5 \%$ & $4.7 \%$ & $16.4 \%$ & $13.1 \%$ & $4.7 \%$ & $2.2 \%$ \\
\hline
\end{tabular}

Table 4. Kolb's Learning Style Inventory for Pre-Athletic Training Students

\begin{tabular}{|c|c|c|c|c|c|}
\hline \multicolumn{5}{|c|}{ Kolb's Learning Style Inventory } \\
\hline Group & Accomodator & Diverger & Converger & Assimilator & No preference \\
\hline Denied & $35.6 \%$ & $21.2 \%$ & $19.9 \%$ & $20.6 \%$ & $2.7 \%$ \\
\hline Admitted 1 time & $28.9 \%$ & $17.0 \%$ & $30.0 \%$ & $22.2 \%$ & $1.5 \%$ \\
\hline Admitted 2 time & $33.3 \%$ & $11.1 \%$ & $0.0 \%$ & $55.6 \%$ & $0.0 \%$ \\
\hline Change of major & $50.0 \%$ & $0.0 \%$ & $0.0 \%$ & $50.0 \%$ & $0.0 \%$ \\
\hline Total & $33.7 \%$ & $19.6 \%$ & $22.6 \%$ & $21.9 \%$ & $2.2 \%$ \\
\hline
\end{tabular}

Table 5. Learning Styles vs. Personality Types of Pre-Athletic Training Students

\begin{tabular}{|c|c|c|c|c|c|c|c|c|}
\hline \multicolumn{7}{|c|}{ Learning Styles and Myers-Briggs Profiles } \\
\hline Group & ISTJ & ISFJ & INFJ & INTJ & ISTP & ISFP & INFP & INTP \\
\hline Accommodator & $5.4 \%$ & $5.4 \%$ & $0.7 \%$ & $0.0 \%$ & $2.0 \%$ & $3.4 \%$ & $0.7 \%$ & $0.7 \%$ \\
\hline Diverger & $10.3 \%$ & $9.2 \%$ & $0.0 \%$ & $0.0 \%$ & $8.1 \%$ & $5.8 \%$ & $1.2 \%$ & $3.5 \%$ \\
\hline Converger & $9.0 \%$ & $8.0 \%$ & $0.0 \%$ & $2.0 \%$ & $2.0 \%$ & $1.0 \%$ & $1.0 \%$ & $2.0 \%$ \\
\hline Assimilator & $20.0 \%$ & $6.3 \%$ & $0.0 \%$ & $1.1 \%$ & $14.7 \%$ & $4.2 \%$ & $1.1 \%$ & $1.1 \%$ \\
\hline No preference & $10.0 \%$ & $0.0 \%$ & $0.0 \%$ & $0.0 \%$ & $30.0 \%$ & $0.0 \%$ & $10.0 \%$ & $0.0 \%$ \\
\hline Total & $10.5 \%$ & $6.8 \%$ & $0.2 \%$ & $0.7 \%$ & $6.6 \%$ & $3.4 \%$ & $1.1 \%$ & $1.6 \%$ \\
\hline
\end{tabular}

\begin{tabular}{|c|c|c|c|c|c|c|c|c|}
\hline \hline \multicolumn{10}{|c|}{ Learning Styles and Myers-Briggs Profiles } \\
\hline Group & ESTP & ESFP & ENFP & ENTP & ESTJ & ESFJ & ENFJ & ENTJ \\
\hline Accommodator & $11.5 \%$ & $12.2 \%$ & $9.5 \%$ & $5.4 \%$ & $21.0 \%$ & $16.2 \%$ & $5.4 \%$ & $0.7 \%$ \\
\hline Diverger & $11.5 \%$ & $11.5 \%$ & $4.6 \%$ & $3.5 \%$ & $10.3 \%$ & $14.9 \%$ & $4.6 \%$ & $1.2 \%$ \\
\hline Converger & $22.0 \%$ & $6.0 \%$ & $8.0 \%$ & $5.0 \%$ & $19.0 \%$ & $7.0 \%$ & $6.0 \%$ & $2.0 \%$ \\
\hline Assimilator & $10.5 \%$ & $4.2 \%$ & $0.0 \%$ & $2.1 \%$ & $14.7 \%$ & $12.6 \%$ & $3.2 \%$ & $4.2 \%$ \\
\hline No preference & $0.0 \%$ & $10.0 \%$ & $0.0 \%$ & $30.0 \%$ & $0.0 \%$ & $10.0 \%$ & $0.0 \%$ & $0.0 \%$ \\
\hline Total & $13.4 \%$ & $8.7 \%$ & $5.9 \%$ & $4.8 \%$ & $16.6 \%$ & $13.0 \%$ & $4.8 \%$ & $1.8 \%$ \\
\hline
\end{tabular}




\section{CONCLUSION:}

The purpose of this study was to identify the preferred learning style and personality types of freshmen in a pre-athletic training program using Kolb's LSI and MBTI over a seven-year period. The secondary purpose was to investigate if students admitted into the professional strand of athletic training program preferred different learning styles or had different personality types from students that were denied admission or changed their major. The Kolb's LSI has been used to identify individuals' learning styles. ${ }^{20}$ Ristori et al investigated learning styles of athletic training students and approved clinical instructors/preceptors. They reported that the most frequent learning style was diverger ( $91 \%$ of preceptors $/ \mathrm{ACls}, 87 \%$ of athletic training students). ${ }^{21}$ Thirteen percent of students and no preceptors/ACls were assimilators, $9 \%$ of preceptors/ACls and none of the students were accommodators, and converging learning style was not preferred by any participants in their study. ${ }^{21}$ Laschinger and Boss reported accommodators and divergers as the most common preferred learning styles in people-oriented professions. ${ }^{22}$ Brower et al reported athletic training students were mostly assimilators (37.5\%), convergers $(27.5 \%)$ followed by divergers $(20 \%)$ and accommodators (15\%). ${ }^{20}$ This investigation suggests widely spread distribution of learning styles in pre-athletic training students. There was no significance in preferred learning styles among pre-athletic training students. However, accommodator style $(33.7 \%)$ was the most predominant learning style, closely followed by convergers $(22.6 \%)$, assimilators $(21.9)$, and divergers $(21.9 \%)$. These data showed that $2.2 \%$ of participants' had no preferred learning style.

Healthcare professionals such as medical students are primarily thinkers and sensors with ESTJ and ISTJ personality types. Physical therapy and occupational therapy students are primarily feelers with ESFJ personality type. ${ }^{16}$ Based on the data of this study, the most common personality types among pre-athletic training students were ESTJ, ESFJ, and ESTP which are similar to other healthcare professionals. Athletic training education is one of the few healthcare education programs that take place during undergraduate studies. The majority of healthcare education programs such as occupational therapy and physical therapy are post-baccalaureate degrees. Thus it is difficult to compare learning styles and personality types of true undergraduate freshmen and masters or doctoral students. However, based on the collected data, it can be concluded that freshmen undergraduate students planning to pursue a degree in athletic training have similar personality types and learning styles as graduate and postgraduate students in healthcare fields.

This study concluded that undergraduate athletic training students demonstrated great diversity in their learning styles and personality types. However, a majority of pre-athletic training students that were denied admission or changed their major preferred the accommodator learning style. Freshmen admitted in the professional strand of the athletic training program preferred converger learning style. These data showed that freshman-level pre-athletic training students prefer extraversion, sensing, thinking, feeling, judging, and perceiving. Athletic training is a healthcare profession working with people. It was not a surprise to see that the most common personality types of freshman-level students interested in athletic training were extroverts who liked working with people. Athletic trainers work with patients and have to use their senses and focus on problems at hand. Thus, the sensing personality type being the most common among pre-athletic training students is appropriate. Thinking is another preferred indicator of pre-athletic training students. Athletic trainers make their decisions based primarily on logic and objective analysis of pros and cons while evaluating every action and its reaction. Sensing is another preferred indicator athletic trainers need to be in order to build a positive rapport with their athletes, patients, coaches, administrators, and other personnel involved in physical activity and health care. Athletic trainers are part of a team and do face evaluations based on personcentered concerns. Athletic trainers need to plan ahead in an organized manner to provide the best care for their patients; thus, judging preference has been common among athletic training students.

Based on the findings of this study, athletic training students prefer hands-on learning, rely on each other to solve a problem, enjoy solving problems, and excel in finding practical use while learning. However, these results were different from previous research. Educators must apply different teaching styles and teaching methods that would benefit all types of students because athletic training students are diverse learners and prefer different learning styles in different situations. Athletic training students benefit from multimodal teaching methods. Educators should consider integrating concrete and abstract material into the curriculum. For example, students often begin their education learning in an abstract-reflexive style and then later develop into abstract-active learners. ${ }^{23}$ The athletic training curriculum should develop from lecture-based passive teacher-centered learning to a problem-based student-centered style. Athletic training students need to have the ability to participate in all different learning style preferences because athletic training is a science-based profession where abstract conceptualization is important. However, they need to have interpersonal relationships with their patients and be able to act effectively in critical situations.

Since research in this area is inconclusive, it would be beneficial to continue investigating preferred learning styles and personality types of athletic training students along with faculty over a period of time. Providing data on changes in personality and learning preference over a period of time of education would provide insight on how athletic training students learn and

() The Internet Journal of Allied Health Sciences and Practice, 2017 
change their personality during their education and whether there is an effect of different curriculum models in athletic training education. Because athletic training education is transitioning from undergraduate to graduate programs, future research comparing learning styles and personality types of undergraduate and graduate athletic training students could reveal beneficial data.

\section{REFERENCES:}

1. Coker CA. Consistency of learning styles of undergraduate athletic training students in the traditional classroom versus the clinical setting. J Athl Train. 2000;35(4);441-4. [PMID: 16558659]

2. Harrelson GL, Leaver-Dunn D, Martin M. Learning styles of athletic training educators [abstracts]. J Athl Train. 2000;35(suppl):S-56.

3. Laurent T, Weidner TG. Clinical-education: setting standards are helpful in the professional preparation of employed, entrylevel certified athletic trainers. J Athl Train. 2002;37(4):248-54. [PMID: 12937553]

4. Kolb AY, Kolb DA. Learning styles and learning spaces: Enhancing experiential learning in higher education. Acad Manag Learn Edu. 2005;4(2):193-212. [DOI 10.5465/AMLE.2005.17268566]

5. Dunn R, Beaudry JS, Klavas A. Survey of research on learning styles. Educ Leadership.1989;46:50-58.

6. Partridge R. Learning styles: a review of selected models. J Nursing Educ. 1983:22(6):243-8. [PMID: 6309718]

7. Griggs D, Griggs SA, Dunn R, Ingham J. Accommodating nursing students' diverse learning styles. Nurse Educ. 1994;19(6):41-5. [PMID: 7862331]

8. Kayes DC. Internal validity and reliability of Kolb's Learning Style Inventory version 3 (1999). J Bus Psychol. 2005;20(2):249-57.

9. Kolb AY. The Kolb Learning Style Inventory-Version3.12005 technical specifications. Boston, MA: Hay Resource Direct; 2005.

10. Kolb DA. Learning Style Inventory. Boston, MA: McBer and Company; 1985.

11. Gurpinar E, Hilal B, Tetik C. Learning styles of medical students change in relation to time. Adv Physiol Educ. 2011;35(3):307-11. [PMID 21908841]

12. Schellhase KC. Kolb's experiential theory in athletic training education: a literature review. Athl Train Educ J. 2006;1(2):1827.

13. Walsh K. Learning styles: do they really exist? Med Educ. 2007;41(6):618-20.

14. Adesunloye BA, Adadesanmi $O$, Henriques FM, Ivonye $C$. The preferred learning style among residents and faculty members of an internal medicine residency program. J Natl Med Assoc. 2008;100(2):172-6. [PMID: 18300534]

15. The Myers \& Briggs Foundation. MBTI Basics. Available at: http://www.myersbriggs.org/my-mbti-personality-type/mbtibasics/ Accessed February 15, 2016.

16. Cohen S, Ahmed SS. Comparative assessment of personality profiles in various health care profession students. Perspective on Physician Assistant Education. 1998;9(4):219-22.

17. Myers IB, McCaulley MH, Quent NL, Hammer AL. MBTI Manual: A guide to the development and use of the Myers-Briggs Type Indicator, 3e. Palo Alto, CA: Consulting Psychologists Press, Inc; 2003.

18. Carlyn M. An assessment of the Myers-Briggs type indicator. An assessment of the Myers-Briggs type indicator. $J$ Pers Assess. 1977:41(5):461-73.

19. Myers BP, Myers KD. Myers-Briggs Type Indicator Career Report. Available at: https://career.ucsd.edu/_files/MyersBriggs.pdf Accessed February 8, 2016.

20. Brower KA, Stemmans CL, Ingersoll CD, Langley DJ. An investigation of undergraduate athletic training students' learning styles and program admission success. J Athl Train. 2001;36(2):130-5. [PMID: 12937452]

21. Ristori CA, Eberman LE, Tripp BL, Kaminski TW. Athletic training student learning style. Int J Athl Ther Train.2011;16(2):337.

22. Laschinger HK, Boss MK. Learning styles of baccalaureate nursing students and attitudes towards theory-based nursing. J Prof Nurs. 1989;5(4):215-23. [PMID: 2778223]

23. Bitran M, Zugina D, Pedrals N, Padilla O, Mena B. Medical students' change in learning styles during the course of the undergraduate program: from 'thinking and watching' to 'thinking and doing'. Can Med Educ J. 2012;3(2):86-97. [PMID: 26451190

(C) The Internet Journal of Allied Health Sciences and Practice, 2017 